Article

\title{
Cross-Generation Analysis of e-Book Consumers' Preferences-A Prerequisite for Effective Management of Public Library
}

\author{
Viktor Prokop $\unrhd$ and Jan Stejskal * $\mathbb{C}$ \\ Faculty of Economics and Administration, University of Pardubice, Studentská 84, 53009 Pardubice II, \\ Czech Republic; viktor.prokop@upce.cz \\ * Correspondence: jan.stejskal@upce.cz
}

Received: 3 January 2020; Accepted: 27 January 2020; Published: 29 January 2020

\begin{abstract}
Nowadays, with the growing importance of providing digital services, public libraries offer a wide range of e-books. However, current studies show that reading preferences vary across countries, and identifying e-book demand is therefore difficult. For these reasons, this article focuses on different groups of e-book readers (pensioners, students, economically active) and on factors affecting their attitude to reading e-books, willingness to receive new library services and willingness to pay for them. For the purpose of this analysis, we are using unique data from an online questionnaire survey among readers of the Municipal Library of Prague in 2019 and own binary logistic models. The results show how e-book genres, information preferences and devices for reading e-books primarily affect selected groups of e-book readers. The unwillingness of e-book readers to pay for library services is also evident, especially among students. In the last section, we propose some practical implications that could help to library management and possibly attract more e-book readers from different groups.
\end{abstract}

Keywords: library; e-books; customer preferences; cross-generation analysis

\section{Introduction}

An e-book is a digital object with textual and/or other content, which arises as a result of integrating the familiar concept of a book with features that can be provided in an electronic environment [1]. E-books have been commercialized since approximately 2008. Richter [2] and some other scholars expected the e-books to gradually push printed (or paper) books out of the market. E-books have a number of advantages over paper books. For readers, this is primarily related to the convenience of accessing a book that is only associated with Internet access. For publishers, e-books have extremely low reproduction and distribution costs.

However, expectations have not been met. E-books have not been accepted by consumers and have become merely an extension of the service offer [3]. There are varying trends in the popularity of reading e-materials in different countries, which are often fashionable and highly dependent on the economic situation of the society. Another important determinant is the IT maturity of consumers (readers), which significantly shape their consumer preferences and behaviors.

Consumer behavior studies and consumer preferences are analyzed in a number of studies. They are trying to explain how it is possible that some countries are growing (e.g., across the EU in 2016, e-book sales increased), while, in the US and the UK, for example, there have been significant declines. Declining trends in e-books are sometimes accompanied by a reversed tendency in paper books; this particular consumer behavior was observed in the US in 2016 and 2017 [4].

The willingness of consumers to pay for the provided e-services plays a significant role in the whole issue [5,6]. This is a determinant that has been addressed by very few authors. Read et al. [7] or 
Waheed et al. [8] combines the unwillingness to pay for e-books with the reader expecting a tangible product, which disrupts his vision and changes consumer preferences and behavior. Atasoy and Morewedge [9] confirm with their results that digital goods are less able to evoke a psychological sense of ownership. On the other hand, it should be emphasized that e-books are economically very profitable and that librarians and publishers perceive them as an interesting business product. Therefore, it remains necessary to pay attention to consumer e-book behavior and to address their willingness to pay for a product as specific as e-books.

The remaining sections will focus on theoretical background and the methodology employed for the empirical analysis. Analysis and discussion of the data will follow. The last section will delineate the conclusion and recommendation as the implication for library managements.

\section{Theoretical Background}

E-books have been a frequent topic of discussion for at least two decades (however, the first discussions began in the 1980s-e.g., Creed, Dennis, and Newstead [10]). After their enlargement, studies began to appear on the comparison of paper and electronic books [11-14]. Some of them define positives, especially in the field of education or publishing, reading newspapers and literature [15]. E-books can be easily updated to correct bugs and add information. The reader can use full text search and work with text much more effectively in their education [16]. You can make notes in the e-text and underline them without damaging the original paper book. In addition, it is possible to use embedded links, hyperlinks leading to additional information, without the reader having to look for them. Of course, there are multimedia such as photos, moving pictures and sound. E-books are also suitable for people with disabilities who, thanks to modern technologies, are allowed access to the content of books.

However, it is necessary to recall that the extension of the possibilities, features or availability of e-material has been and is primarily determined by (a) the degree of technological advancement and (b) the ability of readers (IT literacy). Again, in this context, various studies have begun to address the outcomes of IT progress-especially for readers and the media (e.g., Nielsen [17], McDowell and Twal [18], etc.). One study introduces the term "the next e-reader generation" $[19,20]$ when reading it is necessary to distinguish whether this describes an e-reader as a technical device or an e-reader as a person who reads e-books. The context needs to be monitored). It points to the advent of a new generation of readers. Siegenthaler, Bergamin, Wurtz and Groner [19] report that problems with the e-reader (need for updating, broken reader, unreadable image, etc.) can negatively affect the reader's behavior and discourage him from e-reading.

The second group of researchers began to address readers, their preferences, behavior and ability to use IT media. Scholars Gibson and Gibb [21] define second-generation e-book readers in their study. They are based on a summary of previous studies on e-books and their readers. They rely on the conclusion that the first-generation e-readers were dependent on primitive e-readers (IT device), which offered almost no other option than "read only". They state that the new generation delivers "such as e-ink displays, even lighter weights, larger storage capacities, and longer battery life. E-ink is an important technological development as it reduces screen." These features of e-readers allow readers to use other services, or make their reading experience more intense [22]. Based on the innovations arising from the ICT development, it is necessary to reflect on the behavior of readers who prefer e-books. It is necessary to focus not only on users of selected e-readers (devices; [23]), as the current market allows the possibility to work with e-materials in different ways (reader, smartphone, computer, smart TV, etc.). Antón, Camarero and Rodríguez [24] encourage further research into the behavior of e-book readers, stating that libraries and book publishers should target two distinct consumer groups-ICT lovers and book lovers, both of whom have different preferences according to scholars and service requirements.

There are few studies that, however, look at the behavior of e-book readers from a micro-perspective, specifically analyzing the consumer behavior of selected specific groups of readers. The most frequently analyzed specific group are students. As e-books and e-materials are used in education, there are a number of studies, e.g., Huang and Liang [25], who studied the individual reading behavior of primary 
school students. Their conclusions argue that students are less likely to read e-books than ordinary paper books and propose adjustments in learning practices. Scholars Qazi, Razaand Shah [26] analyzed the readiness of high school students to read e-books. They found the determinants of readiness to read e-books: compatibility, ease-of-use, user-friendliness, trialability, and found that access to and general awareness of e-books has a significant impact and a positive effect on students' behavioral intent. Scholar Foasberg [27] examines university students. The conclusions show that readiness to read e-books is associated with the possession of an e-book reader, and generally concludes that university students are pragmatically willing to read e-books if they need them to study (the same results were published in [28]).

The other two social groups are economically active and pensioners. Economically active are all other researches, unless they are aimed at students. Researchers use a basic set of economically active people for empirical investigations. For example, Shin [29] conducted its research on a mixed sample where the majority of the population were economically active people. Jonas and Sirkeci [30] also deal with reading e-books, but illegally downloaded e-books. Like others, they study a mixed sample where about half of the respondents were economically active, the rest were university students. By doing this, scholars find out what the preferences of the whole group of consumers are, but they cannot say anything about the individual preferences of the individual groups (young-medium-old customers), whose preferences certainly differ significantly. The results of such studies are therefore difficult to use for marketing purposes, and do not provide sufficient information for library management (e.g., if library management wants to introduce a new service, it is difficult to determine for whom and what parameters it should have). Therefore, it seems necessary to conduct research for individual groups of consumers and to obtain preference data separately.

Therefore, the aim of our study is to address three main socio-economic groups (students, economically active people and pensioners) separately and to analyse the attributes and determinants of their willingness to read e-books. The research will also include the question of willingness to pay for e-books, as different answers can be expected for individual research groups.

\section{Data and Methodology}

The online quantitative questionnaire survey to determine the respondents' answers among readers of the Municipal Library of Prague (MLP) in 2019 was used. In total, the survey sample size is N $=1334$ (readers of the MLP 15+). Data collection method CAWI (Computer-assisted web interviewing) was conducted by the sociological agency Sociores and the response rate was $17 \%$ (average time of filling in the questionnaire was $9 \mathrm{~min}$ and $12 \mathrm{~s}$ ).

Information about the research groups is shown in Table 1. For research purposes, we present the characteristics of both the target group and the subsequent focus group (i.e., e-book readers. They are defined by indicating in the questionnaire that they have read at least one e-book in the last year; for details see Table 2).

Table 1. Socio-economic information about the research groups.

\begin{tabular}{llll}
\hline & & $\begin{array}{l}\text { Target Group } \\
\text { (All Readers) } \\
\mathbf{( N = 1 3 3 4 )}\end{array}$ & $\begin{array}{l}\text { Focus Group } \\
\text { (e-Book Readers) } \\
\text { (N = 423) }\end{array}$ \\
\hline \multirow{2}{*}{$\begin{array}{l}\text { Gender } \\
\text { information }\end{array}$} & Woman & $1021(76.54 \%)$ & $307(72.57 \%)$ \\
& Non & $288(21.59 \%)$ & $109(25.76 \%)$ \\
& No answer & $25(1.87 \%)$ & $7(1.67 \%)$ \\
\hline \multirow{2}{*}{$\begin{array}{l}\text { Highest } \\
\text { level of } \\
\text { education }\end{array}$} & Elementary school & $44(3.30 \%)$ & $22(5.20 \%)$ \\
& Secondary school (including apprenticeship) & $46(3.45 \%)$ & $9(2.13 \%)$ \\
& Full secondary with graduation, higher vocational & $482(36.13 \%)$ & $133(31.44 \%)$ \\
& University & $742(55.62 \%)$ & $254(60.05 \%)$ \\
& No answer & $20(1.50 \%)$ & $5(1.18 \%)$ \\
\hline
\end{tabular}


Table 1. Cont.

\begin{tabular}{|c|c|c|c|}
\hline & & $\begin{array}{l}\text { Target Group } \\
\text { (All Readers) } \\
(\mathrm{N}=1334)\end{array}$ & $\begin{array}{l}\text { Focus Group } \\
\text { (e-Book Readers) } \\
(\mathrm{N}=423)\end{array}$ \\
\hline \multirow{7}{*}{$\begin{array}{l}\text { Economic } \\
\text { situation }\end{array}$} & Economically active & $786(58.92 \%)$ & $256(60.52 \%)$ \\
\hline & Pensioner & $233(17.47 \%)$ & $38(8.98 \%)$ \\
\hline & Student & $176(13.19 \%)$ & $90(21.28 \%)$ \\
\hline & Housewife, maternity leave & $80(6.00 \%)$ & $27(6.38 \%)$ \\
\hline & Unemployed & $15(1.12 \%)$ & $6(1.42 \%)$ \\
\hline & Other & $28(2.10 \%)$ & $2(0.47 \%)$ \\
\hline & No answer & $16(1.20 \%)$ & $4(0.95 \%)$ \\
\hline \multirow{7}{*}{$\begin{array}{l}\text { Household's } \\
\text { net monthly } \\
\text { income }\end{array}$} & Less than $15000 \mathrm{CZK}$ & $73(5.47 \%)$ & $12(2.84 \%)$ \\
\hline & $15000 \mathrm{CZK}-29999 \mathrm{CZK}$ & $252(18.89 \%)$ & $70(16.55 \%)$ \\
\hline & $30000 \mathrm{CZK}$ - $44999 \mathrm{CZK}$ & $302(22.64 \%)$ & $102(24.11 \%)$ \\
\hline & $45000 \mathrm{CZK}$ - $59999 \mathrm{CZK}$ & $227(17.02 \%)$ & $78(18.44 \%)$ \\
\hline & $60000 \mathrm{CZK}$ - 74999 CZK & $106(7.95 \%)$ & $40(9.46 \%)$ \\
\hline & $75000 \mathrm{CZK}$ and more & $102(7.65 \%)$ & $45(10.63 \%)$ \\
\hline & No answer & $272(20.39 \%)$ & $76(17.97 \%)$ \\
\hline
\end{tabular}

Note: $1 \mathrm{EUR}=25 \mathrm{CZK}$

Table 2. Socio-economic information about focus groups.

\begin{tabular}{|c|c|c|c|c|c|c|}
\hline & \multicolumn{2}{|c|}{ Students } & \multicolumn{2}{|c|}{ Pensioners } & \multicolumn{2}{|c|}{ Economically Active } \\
\hline & in target group & as an E-book readers & in target group & as an E-book readers & in target group & as an E-book readers \\
\hline \multicolumn{7}{|c|}{ Gender Information } \\
\hline Woman & $135(76.7 \%)$ & $69(76.67 \%)$ & $170(72.96 \%)$ & $25(65.79 \%)$ & $602(76.59 \%)$ & $179(69.92 \%)$ \\
\hline Man & $39(22.2 \%)$ & $19(21.11 \%)$ & $60(25.75 \%)$ & $13(34.21 \%)$ & $178(22.65 \%)$ & $76(29.69 \%)$ \\
\hline No Ans. & $2(1.14 \%)$ & $2(2.22 \%)$ & $3(1.29 \%)$ & $0(0 \%)$ & $6(0.76 \%)$ & $1(0.39 \%)$ \\
\hline \multicolumn{7}{|c|}{ Highest Level of Education } \\
\hline A & $43(24.43 \%)$ & $22(24.44 \%)$ & $0(0 \%)$ & $0(0 \%)$ & $1(0.13 \%)$ & $0(0 \%)$ \\
\hline B & $6(3.41 \%)$ & $3(3.33 \%)$ & $9(3.86 \%)$ & $2(5.26 \%)$ & $22(2.80 \%)$ & $4(1.56 \%)$ \\
\hline $\mathrm{C}$ & $85(48.30 \%)$ & $46(51.11 \%)$ & $103(44.21 \%)$ & $15(39.47 \%)$ & $261(33.21 \%)$ & $66(25.78 \%)$ \\
\hline D & $40(22.72 \%)$ & $1921.11 \%)$ & $121(51.93 \%)$ & $21(55.26 \%)$ & $498(63.36 \%)$ & $185(72.27 \%)$ \\
\hline No Ans. & $2(1.14 \%)$ & $0(0 \%)$ & $0(0 \%)$ & $0(0 \%)$ & $4(0.51 \%)$ & $1(0.39 \%)$ \\
\hline \multicolumn{7}{|c|}{ Household's Net Monthly Income } \\
\hline E & $12(6.81 \%)$ & $5(5.56 \%)$ & $44(18.89 \%)$ & $4(10.53 \%)$ & $12(1.53 \%)$ & $3(1.17 \%)$ \\
\hline $\mathbf{F}$ & $23(13.07 \%)$ & $9(10 \%)$ & $86(36.91 \%)$ & $13(34.21 \%)$ & $124(15.78 \%)$ & $41(16.02 \%)$ \\
\hline G & $36(20.45 \%)$ & $18(20 \%)$ & $40(17.17 \%)$ & $10(26.31 \%)$ & $189(24.05 \%)$ & $62(24.22 \%)$ \\
\hline $\mathbf{H}$ & $30(17.05 \%)$ & $19(21.11 \%)$ & $11(4.72 \%)$ & $1(2.63 \%)$ & $160(20.36 \%)$ & $51(19.92 \%)$ \\
\hline I & $20(11.36 \%)$ & $10(11.11 \%)$ & $2(0.86 \%)$ & $0(0 \%)$ & $81(10.31 \%)$ & $29(11.33 \%)$ \\
\hline $\mathbf{J}$ & $12(6.81 \%)$ & $6(6.67 \%)$ & $3(1.29 \%)$ & $0(0 \%)$ & $74(9.41 \%)$ & $36(14.06 \%)$ \\
\hline No Ans. & $43(24.43 \%)$ & $23(25.56 \%)$ & $47(20.17 \%)$ & $10(26.32 \%)$ & $146(18.58 \%)$ & $34(13.28 \%)$ \\
\hline Total & 176 & 90 & 233 & 38 & 786 & 256 \\
\hline
\end{tabular}

This research includes two parts. In the first part, we focus on the entire sample of e-book readers and on the factors that influenced their willingness to read e-books by asking the following question:

Have you read, studied or downloaded an e-book in the last 12 months?

The chosen factors were divided into four groups (note that selected factors were chosen according to data availability) and were based on the research questions that were asked in the questionnaire. These are:

- EQUIP: Do you use any of the following devices that can be used to read e-books (smartphone; tablet; laptop/computer; e-book reader)?

- GEN: Please select a maximum of five genres of interest from the e-book genres (poetry; drama; fiction-Czech and world novel; fiction-novels for women; fiction-historical novel; fiction- 
books for children; fiction-detective; fiction-humour; fiction-science fiction and fantasy; non-fiction-facts; non-fiction-travelogues; non-fiction-the fates of the famous).

- ECO: Which option best describes your economic situation (economically active; pensioner; student; housewife; unemployed)?

- EDU: What is your highest level of education (elementary school; secondary school including apprenticeship; full secondary with graduation, higher vocational; university)?

In the second part, we focused on the three most important (largest) generation groups-students, pensioners, economically active for the cross-generation analysis. For each group we created three research models focused on the following questions:

- $\quad$ M1: Have you read, studied or downloaded an e-book in the last 12 months?

- M2: The Municipal Library of Prague is considering introducing a new service-“e-book lending", i.e., the possibility to read an e-book through the application and for a limited period of time. This would mainly be book novelties by contemporary Czech and world authors. Would you be interested in such a service?

- M3: Would you also be interested in such a service if it was a paid service?

As selected factors investigating the behaviour (responses) of selected groups of readers were also chosen EQUIP and GEN, but we also add:

- INF: The library can inform about new e-books in various ways. How would you like it most (e-mail; edition plan once a year by e-mail; library website; library Facebook; library notice board; printed edition plan in the library; through librarians)?

- Moreover, for the groups of pensioners and economically active, we also add EDU and information about households' net monthly income:

- INC: Please select a category that corresponds to the net monthly income of your entire household (Less than 15000 CZK; 15000 CZK - 29999 CZK; 30000 CZK - 44999 CZK; 45000 CZK - 59999 CZK; 60 000 CZK - 74999 CZK; 75000 CZK and more).

As the selected variables (questions) are binary, we are using binary logistic regression models that are also commonly used for the purposes of analysis within users of digital services and e-books (see e.g., Zhang and Kudva [31], Hallikainen et al. [32]). We study the relationship between a set of explanatory variables (selected questions-independent variables) and discrete responses (dependent variables-answers; for more information, see, e.g., Prokop et al. [33] or Prokop and Stejskal [34]).

\section{Results}

The first step of our analysis was to examine the entire sample that was empirically obtained. All respondents (target group) answered that they had read at least one e-book in the last 12 months. As mentioned earlier, this is a standard procedure for any analysis that does not respect the different preferences of cross-generation groups. The results are shown in Table 3.

The results clearly show that e-readers in the target group use e-readers (device) for reading, and rarely laptops (PC). E-readers read science fiction and fantasy, poetry, and historical novels electronically most often. In terms of age, the most common e-reader is a student (high strength), then economically active or inactive people. Analysis of all respondents did not reveal that pensioners liked reading e-books. An interesting finding is that, in the overall sample, there was no confirmation of the relationship between education and the popularity of e-books (note: only university and full secondary with graduation/higher vocational education were chosen because of number of answers allowing the running of the analysis). 
Table 3. Analysis willingness to read e-books: target group.

\begin{tabular}{|c|c|c|c|}
\hline Group & Variable & $p$-Value & $B$ Coefficient \\
\hline \multirow{4}{*}{ EQUIP } & Smartphone & 0.695 & 0.073 \\
\hline & Tablet & 0.152 & 0.254 \\
\hline & Laptop/computer & $0.063 *$ & -0.315 \\
\hline & E-book reader & $0.000 * * *$ & 1.757 \\
\hline \multirow{12}{*}{ GEN } & Poetry & $0.044^{* *}$ & 0.637 \\
\hline & Drama & 0.827 & 0.047 \\
\hline & Fiction-Czech and world novel & 0.549 & -0.100 \\
\hline & Fiction-Novels for Women & 0.123 & -0.356 \\
\hline & Fiction-Historical novel & 0.093 * & -0.310 \\
\hline & Fiction-Books for children & 0.202 & 0.292 \\
\hline & Fiction-Detective & 0.889 & -0.024 \\
\hline & Fiction-Humour & 0.694 & -0.069 \\
\hline & Fiction-Science fiction and fantasy & $0.001 * * *$ & 0.569 \\
\hline & Non-fiction-Facts & 0.159 & 0.239 \\
\hline & Non-fiction-Travel. & 0.620 & -0.091 \\
\hline & Non-fiction-The fates of the famous & 0.065 * & -0.399 \\
\hline \multirow{5}{*}{ ECO } & Economically Active & $0.040 * *$ & 1.656 \\
\hline & Pensioner & 0.163 & 1.156 \\
\hline & Student & $0.003^{* * *}$ & 2.471 \\
\hline & Housewife & $0.074 *$ & 1.534 \\
\hline & Unemployed & $0.016^{* *}$ & 2.656 \\
\hline \multirow{2}{*}{ EDU } & University & 0.162 & 1.656 \\
\hline & Full secondary with graduation/higher vocational & 0.224 & 0.653 \\
\hline \multirow{2}{*}{\multicolumn{2}{|c|}{$\begin{array}{l}\text { Cox and Snell } \mathrm{R}^{2} \\
\text { Nagelkerke } \mathrm{R}^{2}\end{array}$}} & & 0.208 \\
\hline & & & 0.278 \\
\hline
\end{tabular}

Legend: * significant at $p<0.10,{ }^{* *}$ significant at $p<0.05,{ }^{* * *}$ significant at $p<0.01$. Source: own research and processing.

As indicated above, we performed cross-generation behaviour analysis and use three models. The results of each group for all three models are shown in Tables 4-6. The research was focused on devices and genres of e-books, as well as the information sources that the given group of readers prefer. Indeed, differences in individual consumer groups can be expected.

The results from the student focus group are shown in Table 4.

The results confirm the same device preferences that a student uses to read e-books. There are slightly different genres that students read using e-books. These are Czech and world novels and science fiction and fantasy novels. Students also prefer e-travel guides. Students respond positively to the offer of e-books-the number of genres they would accept as an e-book has increased. They would also be willing to accept information from the library sent via Facebook. As expected, Czech students would not be willing to pay for e-services provided by libraries.

Pensioners were the second examined group. Here, it was assumed that their willingness to read e-books will be minimal. Similarly, we assumed that, due to their economic situation, they will not want to pay for e-books when there is the same substitute in the form of a paper book provided free of charge by the library. Educational information (EDU) and household income (INC) were added to the variables. The results are shown in Table 5.

The results show confirmation of our hypothesis-Czech pensioners read e-books minimally. They are reluctant to accept a change in offer in the form of e-books because they know there are paper books in the library. In addition, cultural, social and economic reasons are also projected. Pensioners are not willing to change their habits, and any "violent" change at the library's initiative would certainly cause their displeasure and an outflow of reading favour. The results confirmed that pensioners do not want to pay for e-books when they are practically not using them. 
Table 4. The readers of e-books: Students.

\begin{tabular}{|c|c|c|c|c|}
\hline \multirow{2}{*}{ Group } & \multirow{2}{*}{ Variable } & M1 & M2 & M3 \\
\hline & & $\begin{array}{l}p \text {-value } \\
(B \text { coef. })\end{array}$ & $\begin{array}{l}p \text {-value } \\
\text { (B coef.) }\end{array}$ & $\begin{array}{l}p \text {-value } \\
\text { (B coef.) }\end{array}$ \\
\hline \multirow{4}{*}{ EQUIP } & Smartphone & $0.929(-0.090)$ & $0.591(-0.621)$ & $0.397(-0.668)$ \\
\hline & Tablet & $0.017(2.992) * *$ & $0.661(0.448)$ & $0.110(0.927)$ \\
\hline & Laptop/computer & $0.424(-0.645)$ & $0.841(-0.181)$ & $0.725(0.218)$ \\
\hline & E-book reader & $0.031(2.360) * *$ & $0.446(0.781)$ & $0.550(0.379)$ \\
\hline \multirow{12}{*}{ GEN } & Poetry & $0.444(0.993)$ & $0.144(-1.812)$ & $0.610(-0.441)$ \\
\hline & Drama & $0.560(-0.592)$ & $0.240(1.264)$ & $0.242(0.777)$ \\
\hline & Fiction-Czech and world novel & $0.054(1.732)^{*}$ & $0.795(-0.222)$ & $0.855(-0.108)$ \\
\hline & Fiction-Novels for Women & $0.638(0.592)$ & $0.257(1.229)$ & $0.165(-1.112)$ \\
\hline & Fiction-Historical novel & $0.062(-1.877) *$ & $0.015(3.488)^{* *}$ & $0.361(0.545)$ \\
\hline & Fiction-Books for children & $0.739(-0.416)$ & $0.850(-0.323)$ & $0.759(0.273)$ \\
\hline & Fiction-Detective & $0.951(0.061)$ & $0.520(-0.580)$ & $0.181(-0.759)$ \\
\hline & Fiction-Humour & $0.549(-0.516)$ & $0.008(3.069)^{* * *}$ & $0.560(0.345)$ \\
\hline & Fiction-Science fiction and fantasy & $0.051(1.695)$ * & $0.004(2.710)^{* * *}$ & $0.933(-0.047)$ \\
\hline & Non-fiction-Facts & $0.475(-0.609)$ & $0.275(0.881)$ & $0.332(0.562)$ \\
\hline & Non-fiction-Travel. & $0.096(1.598)^{*}$ & $0.088(-1.655) *$ & $0.327(-0.808)$ \\
\hline & Non-fiction-The fates of the famous & $0.865(-0.166)$ & $0.048(2.571)^{* *}$ & $0.710(0.266)$ \\
\hline \multirow{7}{*}{ INF } & E-mail & $0.044(-1.928)^{* *}$ & $0.710(0.314)$ & - \\
\hline & Edition plan once a year by e-mail & $0.967(0.037)$ & $0.557(0.582)$ & - \\
\hline & Library website & $0.279(0.884)$ & $0.205(1.038)$ & - \\
\hline & Library Facebook & $0.338(1.003)$ & $0.002(3.998)^{* * *}$ & - \\
\hline & Library notice board & $0.393(-0.972)$ & $0.006(-3.326)^{* * *}$ & - \\
\hline & Printed edition plan in the library & $0.083(2.293) *$ & $0.542(-0.654)$ & - \\
\hline & Through librarians & $0.942(0.117)$ & $0.456(1.220)$ & - \\
\hline Cox and Snell $\mathrm{R}^{2}$ & & 0.384 & 0.365 & 0.242 \\
\hline Nagelkerke $\mathrm{R}^{2}$ & & 0.532 & 0.590 & 0.334 \\
\hline
\end{tabular}

Legend: ${ }^{*}$ significant at $p<0.10,{ }^{* *}$ significant at $p<0.05,{ }^{* * *}$ significant at $p<0.01$. Source: own research and processing. 
Table 5. The readers of e-books: Pensioners.

\begin{tabular}{|c|c|c|c|c|}
\hline \multirow{2}{*}{ Group } & \multirow{2}{*}{ Variable } & M1 & M2 & M3 \\
\hline & & $p$-value ( $B$ coef.) & $p$-value ( $B$ coef.) & $p$-value ( $B$ coef.) \\
\hline \multirow{4}{*}{ EQUIP } & Smartphone & $0.232(-1.389)$ & $0.498(-0.587)$ & $0.212(-1.518)$ \\
\hline & Tablet & $0.625(0.623)$ & $0.100(1.683)$ & $0.019(5.020) * *$ \\
\hline & Laptop/computer & $0.597(-0.524)$ & $0.181(-1.060)$ & $0.804(-0.304)$ \\
\hline & E-book reader & $0.001(4.153)^{* * *}$ & $0.342(1.041)$ & $0.075(4.610)^{*}$ \\
\hline \multirow{12}{*}{ GEN } & Poetry & $0.701(0.617)$ & $0.069(-2.941) *$ & - \\
\hline & Drama & $0.590(-0.765)$ & $0.142(2.721)$ & $0.121(-3.886)$ \\
\hline & Fiction-Czech and world novel & $0.419(0.923)$ & $0.699(0.308)$ & $0.352(1.330)$ \\
\hline & Fiction-Novels for Women & $0.644(0.684)$ & $0.753(0.322)$ & $0.674(-0.725)$ \\
\hline & Fiction-Historical novel & $0.093(1.860) *$ & $0.731(0.274)$ & $0.206(-1.530)$ \\
\hline & Fiction-Books for children & $0.875(-0.276)$ & $0.030(-4.052) * *$ & $0.082(-6.377) *$ \\
\hline & Fiction-Detective & $0.310(-1.062)$ & $0.818(0.155)$ & $0.338(-1.005)$ \\
\hline & Fiction-Humour & $0.241(1.214)$ & $0.039(1.764) * *$ & $0.088(2.303)$ * \\
\hline & Fiction-Science fiction and fantasy & $0.087(2.513) *$ & $0.089(-1.800) *$ & $0.593(0.956) *$ \\
\hline & Non-fiction-Facts & $0.166(1.875)$ & $0.334(0.996)$ & $0.875(-0.196)$ \\
\hline & Non-fiction-Travel. & $0.141(-1.544)$ & $0.197(-1.002)$ & $0.070(2.639) *$ \\
\hline & Non-fiction-The fates of the famous & $0.404(-0.942)$ & $0.782(0.205)$ & $0.025(2.812)^{* *}$ \\
\hline \multirow{7}{*}{ INF } & E-mail & $0.431(-0.943)$ & $0.046(1.935) * *$ & - \\
\hline & Edition plan once a year by e-mail & $0.625(-0.550)$ & $0.843(0.162)$ & - \\
\hline & Library website & $0.774(0.393)$ & $0.512(0.616)$ & - \\
\hline & Library Facebook & - & - & - \\
\hline & Library notice board & $0.795(-0.869)$ & $0.761(0.506)$ & - \\
\hline & Printed edition plan in the library & $0.684(0.639)$ & $0.076(-1.779) *$ & - \\
\hline & Through librarians & $0.051(4.223) *$ & $0.872(0.231)$ & - \\
\hline \multirow{2}{*}{ EDU } & University & $0.403(3.239)$ & $0.653(-1.053)$ & $0.251(-4.440)$ \\
\hline & Full secondary with graduation/higher vocational & $0.349(3.637)$ & $0.458(-1.707)$ & $0.489(-2.559)$ \\
\hline \multirow{6}{*}{ INC } & Less than $15000 \mathrm{CZK}$ & - & - & - \\
\hline & $15000 \mathrm{CZK}-29999 \mathrm{CZK}$ & $0.686(-0.515)$ & $0.817(0.199)$ & $0.563(0.737)$ \\
\hline & $30000 \mathrm{CZK}-44999 \mathrm{CZK}$ & $0.637(0.606)$ & $0.568(-0.569)$ & $0.801(-0.354)$ \\
\hline & $45000 \mathrm{CZK}-59999 \mathrm{CZK}$ & $0.791(0.520)$ & - & $0.497(2.003)$ \\
\hline & $60000 \mathrm{CZK}-74999 \mathrm{CZK}$ & - & - & - \\
\hline & $75000 \mathrm{CZK}$ and more & - & $0.090(-4.317) *$ & - \\
\hline Cox and Snell $R^{2}$ & & 0.458 & 0.329 & 0.454 \\
\hline Nagelkerke $R^{2}$ & & 0.651 & 0.447 & 0.607 \\
\hline
\end{tabular}

Legend: * significant at $p<0.10,{ }^{* *}$ significant at $p<0.05,{ }^{* * *}$ significant at $p<0.01$. Source: own research and processing. 
Table 6. The readers of e-books: Economically active.

\begin{tabular}{|c|c|c|c|c|}
\hline \multirow{2}{*}{ Group } & \multirow{2}{*}{ Variable } & M1 & M2 & M3 \\
\hline & & $p$-value ( $B$ coef.) & $p$-value ( $B$ coef.) & $p$-value ( $B$ coef.) \\
\hline \multirow{4}{*}{ EQUIP } & Smartphone & $0.252(0.327)$ & $0.002(0.905)^{* * *}$ & $0.733(0.100)$ \\
\hline & Tablet & $0.142(0.401)$ & $0.565(0.177)$ & $0.049(0.575)^{* *}$ \\
\hline & Laptop/computer & $0.160(-0.372)$ & $0.600(-0.150)$ & $0.111(0.438)$ \\
\hline & E-book reader & $0.000(2.290)^{* * *}$ & $0.001(1.119)^{* * *}$ & $0.001(1.024)^{* * *}$ \\
\hline \multirow{12}{*}{ GEN } & Poetry & $0.824(0.130)$ & $0.878(0.111)$ & $0.136(-0.877)$ \\
\hline & Drama & $0.809(0.076)$ & $0.203(0.490)$ & $0.366(0.286)$ \\
\hline & Fiction-Czech and world novel & $0.185(-0.347)$ & $0.417(0.226)$ & $0.390(0.227)$ \\
\hline & Fiction-Novels for Women & $0.101(-0.574)$ & $0.945(0.027)$ & $0.425(-0.275)$ \\
\hline & Fiction-Historical novel & $0.228(-0.331)$ & $0.136(0.483)$ & $0.648(0.125)$ \\
\hline & Fiction-Books for children & $0.079(0.533) *$ & $0.571(0.211)$ & $0.629(0.156)$ \\
\hline & Fiction-Detective & $0.212(-0.326)$ & $0.173(0.389)$ & $0.493(0.181)$ \\
\hline & Fiction-Humour & $0.403(-0.230)$ & $0.266(0.354)$ & $0.499(-0.186)$ \\
\hline & Fiction-Science fiction and fantasy & $0.531(0.166)$ & $0.401(-0.248)$ & $0.414(-0.221)$ \\
\hline & Non-fiction-Facts & $0.142(0.388)$ & $0.897(0.038)$ & $0.552(0.163)$ \\
\hline & Non-fiction-Travel. & $0.725(-0.095)$ & $0.580(0.163)$ & $0.701(-0.108)$ \\
\hline & Non-fiction-The fates of the famous & $0.005(-0.954)^{* * *}$ & $0.523(-0.229)$ & $0.573(-0.187)$ \\
\hline \multirow{7}{*}{ INF } & E-mail & $0.985(0.005)$ & $0.082(0.524) *$ & - \\
\hline & Edition plan once a year by e-mail & $0.046(-0.508) * *$ & $0.802(0.081)$ & - \\
\hline & Library website & $0.428(0.216)$ & $0.880(-0.046)$ & - \\
\hline & Library Facebook & $0.090(0.539) *$ & $0.010(1.053) * *$ & - \\
\hline & Library notice board & $0.321(0.457)$ & $0.908(0.059)$ & - \\
\hline & Printed edition plan in the library & $0.195(0.631)$ & $0.474(0.418)$ & - \\
\hline & Through librarians & $0.452(-0.406)$ & $0.879(0.103)$ & - \\
\hline \multirow{2}{*}{ EDU } & University & $0.663(0.387)$ & $0.104(1.419)$ & $0.046(1.723)^{* *}$ \\
\hline & Full secondary with graduation/higher vocational & $0.914(-0.097)$ & $0.069(1.601) *$ & $0.041(1.767) * *$ \\
\hline \multirow{6}{*}{ INC } & Less than $15000 \mathrm{CZK}$ & - & - & - \\
\hline & $15000 \mathrm{CZK}-29999 \mathrm{CZK}$ & $0.639(0.493)$ & $0.724(0.338)$ & $0.164(-1.458)$ \\
\hline & $30000 \mathrm{CZK}-44999 \mathrm{CZK}$ & $0.601(0.546)$ & $0.398(0.809)$ & $0.141(-1.528)$ \\
\hline & $45000 \mathrm{CZK}-59999 \mathrm{CZK}$ & $0.989(0.014)$ & $0.990(0.012)$ & $0.307(-1.070)$ \\
\hline & $60000 \mathrm{CZK}-74999 \mathrm{CZK}$ & $0.786(-0.294)$ & $0.973(-0.033)$ & $0.250(-1.238)$ \\
\hline & $75000 \mathrm{CZK}$ and more & $0.694(0.424)$ & $0.859(0.177)$ & $0.153(-1.533)$ \\
\hline Cox \& Snell $\mathrm{R}^{2}$ & & 0.259 & 0.137 & 0.107 \\
\hline Nagelkerke $\mathrm{R}^{2}$ & & 0.345 & 0.208 & 0.148 \\
\hline
\end{tabular}

Legend: * significant at $p<0.10,{ }^{* *}$ significant at $p<0.05,{ }^{* * *}$ significant at $p<0.01$. Source: own research and processing. 
This result is important in the methodology of identifying consumer preferences. Inclusion of the pensioners focus group in the target group causes a considerable lack of clarity in the results, especially in the area of public libraries.

The last focus group are economically active residents. Their results are shown in Table 6.

This focus group is more willing to read e-books than pensioners. They use e-readers (device) and would start using smartphones or tablets for new e-services. However, the results did not significantly confirm that the economically active prefer e-books over paper books. Similarly, the assumption that they would be more willing to pay for e-books if the library offered them only for a fee was not confirmed. These are quite surprising results. The results can be explained mainly by the habits of economically active people, as well as the high availability of e-books on the Internet (mostly available free of charge). Many of the economically active population prefer paper-made books, linking them to experiences they would not experience with an e-book. E-books are preferred as a substitute when it is not practical or technically possible to carry a paper book. However, the results and justifications can only be applied to Czech MLP readers.

\section{Discussion}

It is evident that screen-based reading is becoming more popular because e-books are able to provide individualized and on-demand multimedia features [35]. Public (academic) libraries are therefore choosing to purchase e-books rather than the print versions because of change in collection practice, accessibility, lower costs and space [36]. However, e-books are not being used as much as they should be. For these reasons, researchers tend to find the preferences of e-book readers, similarly to the preferences of digital service users (e.g., Bertot et al. [37], Hallikainen et al. [32]. Most of these studies focus on the whole group of e-book readers (or on university students). But these results are too general and do not fit individual preferences of different groups of e-books readers. To fill this gap, unlike previous studies, we have primarily focused on individual groups of e-book readers and analyzed the behavior and preferences of pensioners, students and economically active population by using unique data of the Municipal Library of Prague.

The results of our study confirm trends that also appear in other consumer surveys. However, they extend them to the needs of public libraries and their management, who, according to them, can better design their services accordingly. In the case of all respondents, we, for example, confirmed the leading role of e-book readers as significant device that can be used to read e-books. These are important results, because e-book readers commonly receive a very mixed press, with some authors believing they represent the future of reading and, on the other hand, others claiming that reading long texts from a screen is an inherently unpleasant experience and, therefore, will never be popular [38]. As we can see, for MLPs' e-book readers it is a still relevant and important device. Students also prefer tablets for reading e-books. Surprisingly, there are no specific genres that influence their willingness to read e-books more than the others. This is generally associated with a decline in the young generation's interest in reading books. Moreover, if students use book sources, they do not prefer e-books over textbooks regardless of their gender, computer use or comfort with computers [14]. Generally, both users and non-users of e-books, nowadays prefer to use the printed version of textbooks, especially if the text is continuously used [39]. Students reading humor, science fiction and fantasy, and the fates of the famous are also interested in a new service provided by MLP but are not willing to pay for these services. E-book genres also play significant role for pensioners deciding whether they are interested in the new MLPs' services. However, they are not also willing to pay for these services. This is clear, according to the different factors (e.g., economic situation, preferences, and consumptions habits) of these quite different groups. In the case of the economically active population, education level and devices for reading e-books play significant role. From these results, it is clear that library management must focus on the different interests of selected groups to clearly meet their expectations and raise their willingness to read e-books. The introduction of new library services must be considered, but these services should be free of charge or for a symbolic fee. 


\section{Conclusions}

Many of the above studies deal with the behavior of readers. The results are used to innovate the services provided by libraries to better match the expectations and preferences of individual readers. The urgency of these changes is mainly due to ICT progress and changes in individual readers' preferences, but also changes in the way libraries are financed, increased competition from other cultural sectors, etc.

The assumption of the different preferences of selected groups of readers has been documented. This paper brings a new perspective on the behavior and preferences of individual reading groups over previous empirical or marketing surveys (where researchers examined the preferences of an entire consumer group from 15+). These mixed and often averaged results cannot be applied to focus on specific services for select groups of consumers. This is especially true for a service as specific as e-reading or e-book borrowing.

We also recommend library management to target their policy of increasing the e-books offered to three target groups separately. Each of them needs to be informed, or a workshop could be created to show the benefits of, and how to use, e-books and devices. Any strict change in supply that will force readers to read or pay for e-books only (without substitutes in the form of paper books) will result in a reader outflow to other libraries or outside the library market.

This study also has its limitations. One of the limitations is the informative ability of the data, which was obtained only in the MLP, meaning the results can only be related to this. However, the results for other libraries have an approximate predicative ability, as it has been proven by previous surveys that MLP results do not differ significantly from other libraries in the Czech Republic. The second big limitation is the focus group frequency (number of respondents) for both pensioners and students. This could influence the significance of the results; therefore, this should be considered when discussing and using the results.

Further research will focus on the research of individual selected services, such as residential services or digital services, which also represent new types of services that require the application of innovative approaches.

Author Contributions: Both authors participated equally in the creation of this paper. Both authors have read and agreed to the published version of the manuscript.

Funding: This research was funded by Ministry of Culture of the Czech Republic, grant VISK1.

Acknowledgments: We express our thanks to the Sociores Agency, specifically to Pavel Černý, for processing the empirical data from MLP surveys.

Conflicts of Interest: The authors declare no conflict of interest.

\section{References}

1. Vassiliou, M.; Rowley, J. Progressing the definition of “e-book". Libr. Hi Tech 2008, 26, 355. [CrossRef]

2. Richter, F. US Ebook Sales to Surpass Printed Book Sales in 2017. Available online: https://www.statista.com/ chart/1159/ebook-sales-to-surpass-printed-book-sales-in2017/ (accessed on 28 February 2018).

3. Miller, C.C.; Bosman, J. E-books outsell print books at Amazon. New York Times. 20 May 2011. Available online: http://www.nytimes.com/2011/05/20/technology/20amazon.html?nl=todaysheadlines\&emc=tha26\& pagewanted=print (accessed on 2 February 2018).

4. Cheng, Y.; Qiu, L. Persuading Consumers into Buying E-books: The Mediating Role of Perceived Effort. In Proceedings of the 22nd PACIS 2018, Yokohama, Japan, 26-30 June 2018; p. 115.

5. Merickova, B.M.; Halaskova, R. The issue of income redistribution. E+M Ekon. Manag. 2014, 17, 15-26. [CrossRef]

6. Halaskova, M.; Halaskova, R.; Prokop, V. Evaluation of efficiency in selected areas of public services in European Union countries. Sustainability 2018, 10, 4592. [CrossRef]

7. Read, W.; Robertson, N.; McQuilken, L. A novel romance: The technology acceptance model with emotional attachment. Australas. Market. J. 2011, 19, 223-229. [CrossRef] 
8. Waheed, M.; Kaur, K.; Ain, N.; Sanni, S.A. Emotional attachment and multidimensional self-efficacy: Extension of innovation diffusion theory in the context of eBook reader. Behav. Inf. Technol. 2015, 34, 1147-1159. [CrossRef]

9. Atasoy, O.; Morewedge, C.K. Digital goods are valued less than physical goods. J. Consumer Res. 2018, 44, 1343-1357. [CrossRef]

10. Creed, A.; Dennis, I.; Newstead, S. Proof-reading on VDUs. Behav. Inf. Technol. 1987, 6, 3-13. [CrossRef]

11. Galway, L. On the Edge: Statistics and Computing: E-Books and E-Journals: Why Not? Chance 1994, 7, 54-56. [CrossRef]

12. Bennett, L.; Landoni, M. E-books in academic libraries. Electron. Libr. 2005, 23, 9-16. [CrossRef]

13. Nelson, M.R. E-books in higher education: Nearing the end of the era of hype? Educ. Rev. 2008, 43, 40-42.

14. Woody, W.D.; Daniel, D.B.; Baker, C.A. E-books or textbooks: Students prefer textbooks. Comput. Educ. 2010, 55, 945-948. [CrossRef]

15. Siegenthaler, E.; Wurtz, P.; Bergamin, P.; Groner, R. Comparing reading processes on e-ink displays and print. Displays 2011, 32, 268-273. [CrossRef]

16. Bilan, Y.; Simionescu, M.; Mentel, G.; Rozsa, Z. The role of education, individual and economic factors in entrepreneurial initiatives: A microeconomic approach for the Czech Republic, Slovakia and Poland. E+M Ekon. Manag. 2019, 22, 85-102. [CrossRef]

17. Nielsen, J. Kindle 2 usability review. Available online: http://www.useit.com/alertbox/kindle-usabilityreview.html (accessed on 16 November 2009).

18. McDowell, M.; Twal, R. Integrating Amazon Kindle: A seton hall university pilot program. Retrieved on 17 September 2009. Available online: http://www.educause.edu/Resources/IntegratingAmazonKindleASetonH/ 163808 (accessed on 29 January 2020).

19. Siegenthaler, E.; Wurtz, P.; Groner, R. Improving the usability of e-book readers. J. Usability Stud. 2010, 6, 25-38.

20. Stejskal, J.; Hájek, P.; Řehák, T. The economic value of library services for children: The case of the Czech public libraries. Libr. Inf. Sci. Res. 2019, 41, 100963. [CrossRef]

21. Gibson, C.; Gibb, F. An evaluation of second-generation ebook readers. Electron. Libr. 2011, 29, 303-319. [CrossRef]

22. Wilson, R.; Landoni, M. Evaluating the usability of portable electronic books. In Proceedings of the 2003 ACM Symposium on Applied Computing, Melbourne, FL, USA, 9-12 March 2003; pp. 564-568.

23. Landoni, M.; Hanlon, G. E-book reading groups: Interacting with e-books in public libraries. Electron. Libr. 2007, 25, 599-612. [CrossRef]

24. Antón, C.; Camarero, C.; Rodríguez, J. Usefulness, enjoyment, and self-image congruence: The adoption of e-book readers. Psychol. Market. 2013, 30, 372-384. [CrossRef]

25. Huang, Y.M.; Liang, T.H. A technique for tracking the reading rate to identify the e-book reading behaviors and comprehension outcomes of elementary school students. Br. J. Educ. Technol. 2015, 46, 864-876. [CrossRef]

26. Qazi, W.; Raza, S.A.; Shah, N. Acceptance of e-book reading among higher education students in a developing country: The modified diffusion innovation theory. Int. J. Bus. Inf. Syst. 2018, 27, 222-245. [CrossRef]

27. Foasberg, N.M. Adoption of e-book readers among college students: A survey. Inf. Technol. Libr. 2011, 30, 108-128. [CrossRef]

28. Hajek, P.; Stejskal, J. Library usage mining in the context of alternative costs: The case of the municipal library of Prague. Libr. Hi Tech 2017, 35, 558-576. [CrossRef]

29. Shin, D.H. Understanding e-book users: Uses and gratification expectancy model. New Media Soc. 2011, 13, 260-278. [CrossRef]

30. Jonas, O.; Sirkeci, I. Understanding determinants of illegal e-book downloading behaviour in the UK and Germany. Transnatl. Market. J. 2018, 6, 79-100. [CrossRef]

31. Zhang, Y.; Kudva, S. E-books versus print books: Readers' choices and preferences across contexts. J. Assoc. Inf. Sci. Technol. 2014, 65, 1695-1706. [CrossRef]

32. Hallikainen, H.; Alamäki, A.; Laukkanen, T. Lead users of business mobile services. Int. J. Inf. Manag. 2019, 47, 283-292. [CrossRef]

33. Prokop, V.; Stejskal, J. Different influence of cooperation and public funding on innovation activities within German industries. J. Bus. Econ. Manag. 2019, 20, 384-397. [CrossRef] 
34. Prokop, V.; Stejskal, J.; Hudec, O. Collaboration for innovation in small CEE countries. E+M Ekon. Manag. 2019, 22, 130-144. [CrossRef]

35. Huang, Y.M.; Liang, T.H.; Chiu, C.H. Gender differences in the reading of e-books: Investigating children's attitudes, reading behaviors and outcomes. J. Educ. Technol. Soc. 2013, 16, 97-110.

36. Raynard, M. Understanding academic e-books through the diffusion of innovations theory as a basis for developing effective marketing and educational strategies. J. Acad. Librariansh. 2017, 43, 82-86. [CrossRef]

37. Bertot, J.; Estevez, E.; Janowski, T. Universal and contextualized public services: Digital public service innovation framework. Govern. Inf. Q. 2016, 41, 211-222. [CrossRef]

38. Wilson, R. Ebook readers in higher education. Educ. Technol. Soc. 2003, 6, 8-17.

39. Roesnita, I.; Zainab, A.N. The pattern of e-book use amongst undergraduates an Malaysia: A case of to know is to use. Malays. J. Libr. Inf. Sci. 2013, 10, 1-23.

(C) 2020 by the authors. Licensee MDPI, Basel, Switzerland. This article is an open access article distributed under the terms and conditions of the Creative Commons Attribution (CC BY) license (http://creativecommons.org/licenses/by/4.0/). 